\title{
Características dos produtores artesanais dos festivais gastronômicos da cidade de São Paulo
}

\section{Characteristics of artisanal producers of gastronomic festivals in the city of São Paulo}

\author{
Cinthia Rolim de Albuquerque Meneguel ${ }^{1}$
}

A cidade de São Paulo é caracterizada pela ocorrência de inúmeros festivais gastronômicos que recebem formatos diferenciados de acordo com o seu conceito e objetivo. Os festivais são acontecimentos que geram expressões culturais importantes, ilustram práticas sociais da humanidade evidenciadas pelas experiências. São capazes de revelar e compartilhar conhecimento, saberes, crenças e visões de mundo das culturas para com os visitantes que participam, afirmando ou denunciando certos valores sociais estruturais da comunidade celebrante. Observam-se na cidade de São Paulo propostas de festivais gastronômicos focados no fomento do diálogo entre produtores artesanais com os cozinheiros, cientistas e com o público geral. A agricultura familiar brasileira é majoritariamente o setor mais representativo do agro brasileiro e apresenta diversos modos de fazer agricultura, representados por agricultores familiares, artesanais, urbanos, quilombolas, assentamentos agrários e de barragens, sendo uma forma de expressão cultural e social com contribuições no âmbito material e imaterial, considerando como características tradicionais, culturais ou regionais, os processos de elaboração de alimentos que se transmite de geração em geração, conforme a tradição cultural ou que utilizam matérias-primas produzidas na região. Portanto, esta investigação buscou compreender o papel assumido pelos produtores artesanais nos festivais gastronômicos da cidade de São Paulo, por meio da caracterização dos produtores e de seus produtos, identificando o fator patrimonial e o motivacional de participação nos festivais gastronômicos e suas relações. Portanto, para a presente investigação qualitativa, exploratória e descritiva, realizou-se a coleta de dados em fontes primárias e secundárias, observação direta dos festivais, aplicação de questionários semiestruturados com perguntas abertas e fechadas a 103 produtores artesanais expositores dos festivais: Sabor Nacional e Feira Viva. Assim, este estudo permitiu mostrar que o universo dos festivais gastronômicos da cidade de São Paulo oferece aos produtores artesanais uma ação protagonista de inclusão produtiva, condutora e norteadora de ações e narrativas, gerando expressões culturais, compartilhando conhecimento, saberes e vivências, sendo seu pilar principal. Estabelecendo pela alimentação o elo entre o campo e a cidade, apresentando produtores artesanais e tipicidades regionais. Certamente, os produtores artesanais assumem de modo intrínseco a responsabilidade de comunicar valores socioculturais, ambientais e econômicos, enaltecendo a relação do homem com a biodiversidade, conectando o alimento a sua identidade, território e cultura. Incentivando a valorização da cultura alimentar, o resgate e a preservação de tradições e o fortalecimento social.

Palavras-chave: festival; feira; produto artesanal; produtor; São Paulo.

Keywords: festival; market; artisanal product; producer; São Paulo. 